University of Wollongong

Research Online

Faculty of Social Sciences - Papers (Archive) Faculty of Arts, Social Sciences \& Humanities

2015

Geographers and the discourse of an earth transformed: influencing the intellectual weather or changing the intellectual climate?

Noel Castree

University of Wollongong, ncastree@uow.edu.au

Follow this and additional works at: https://ro.uow.edu.au/sspapers

Part of the Education Commons, and the Social and Behavioral Sciences Commons

Research Online is the open access institutional repository for the University of Wollongong. For further information contact the UOW Library: research-pubs@uow.edu.au 


\title{
Geographers and the discourse of an earth transformed: influencing the intellectual weather or changing the intellectual climate?
}

\begin{abstract}
This article considers how geographers might choose to respond to many geoscientists' claims that we are entering 'the age of humans'. These claims, expressed in the concepts of the Anthropocene, planetary boundaries and global tipping points, make epochal claims about Earth surface change that are also farreaching claims upon Earth's current inhabitants. The scale and scope of their normative implications are extraordinarily grand. After describing the content and wider context for these claims, the history of some geographers' engagement with global change research is sketched and their current contributions described. Wider alterations in the modus operandi of global change scientists seem to offer a perfect opportunity for geographers to demonstrate the intellectual and societal value of their discipline's 'integrative' aspirations. However, the article suggests that this opportunity is likely to be used in a rather conservative way that downplays the sort of wide, deep and plural forms of integrative analysis that a post-Holocene world surely calls for. Such forms exist in geography but are currently not, by and large, feeding into wider debates in global change research about how to understand and influence the future of Earth and humanity. The question is: how might they serve to alter the intellectual climate prevailing in global change research as Future Earth becomes the new umbrella for its next phase of development?
\end{abstract}

\section{Keywords}

climate, intellectual, discourse, geographers, changing, earth, weather, transformed, influencing

\section{Disciplines}

Education | Social and Behavioral Sciences

\section{Publication Details}

Castree, N. (2015). Geographers and the discourse of an earth transformed: influencing the intellectual weather or changing the intellectual climate?. Geographical Research, 53 (3), 244-254. 


\title{
Geographers and the discourse of an Earth transformed: influencing the intellectual weather or changing the intellectual climate?
}

\begin{abstract}
This article considers how geographers might choose to respond to many geoscientists' claims that we are entering 'the age of humans'. These claims, expressed in the concepts of the Anthropocene, planetary boundaries and global tipping points, make epochal claims about Earth surface change that are also farreaching claims upon Earth's current inhabitants. The scale and scope of their normative implications are extraordinarily far-reaching. After describing the content and wider context for these claims, the history of some geographers' engagement with global change research is sketched and their current contributions described. Wider alterations in the modus operandi of global change scientists seem to offer a perfect opportunity for geographers to demonstrate the intellectual and societal value of their discipline's 'integrative' aspirations. However, the article suggests that this opportunity is likely to be used in a rather conservative way that downplays the sort of wide, deep and plural forms of integrative analysis that a post-Holocene world surely calls for. Such forms exist in geography but are currently not, by and large, feeding into wider debates in global change research about how to understand and influence the future of Earth and humanity. The question is: how might they serve to alter the intellectual climate prevailing in global change research as Future Earth becomes the new umbrella for its next phase of development?
\end{abstract}

Keywords: the Anthropocene; geoscience, geography; epistemology

\section{Introduction}

'The Anthropocene' (Crutzen \& Stoermer, 2000) is one of three epochal concepts being mobilised by geoscientists to capture the attention of politicians, business leaders, third sector organisations and publics. The other two are 'planetary boundaries' and 'global tipping points' (see Rockström et al., 2009; Steffen et al., 20 I5; Barnosky et al., 2012). Alone and together these ideas suggest humans are on the brink of a 'no analogue' situation (Steffen et al., 2004). Not yet societal keywords, their scientific popularisers hope they graduate from being buzzwords currently commanding the attention of a few thousand academics, journalists and other thought-shapers. The reason is simple enough: if geoscientists across the disciplines are right, we are entering terra incognita by inadvertently ending the relatively benign conditions of the Holocene epoch.

Though science has long made universal claims about the biophysical world, it is rare for them to also be direct claims upon the totality of humanity (present and future), so too political and economic elites worldwide. Yet such is the proclaimed magnitude, scope and scale of the 'human impact' on Earth that geoscientists are sounding the alarm at all points of the compass. Their 
concern extends well beyond anthropogenic climate change to include transformations of nutrient cycles, ecosystems, oceans, and more besides. Sverker Sorlin (2013: 20) dubs them "concerned synthesists" for this reason. The profundity of their pronouncements means that environmental researchers across all the disciplines, along with a plethora of non-academic constituencies, will need to reckon with them in some way.

In this short essay I want to consider how geographers might choose to respond to many geoscientists' claims that we are entering 'the age of humans'. Unlike so many other developments in modern science (e.g. novel anti-cancer drugs or new 'gene drive' technologies), these claims are - for obvious reasons - directly relevant to the research and educational preoccupations of a great many geographers. Indeed, several practitioners have lent their names to one or more of the three concepts mentioned above (for instance, Timothy Lenton and Diana Liverman: see Rockström et al., 2009). Looking ahead, I will argue that a certain cadre of geographers are likely to respond to geoscience's representations of an Earth transformed in ways feasible though not necessarily desirable in the absence of other contributions. Meanwhile, other practitioners with important things to say about these representations seem set to watch from the sidelines.

What is needed, I argue, is a third way between these potentially problematic forms of engagement with, and distance from, international geoscience. This matters for reasons far more important than how Geography's value is perceived outside the discipline. Who will speak for the Earth, and how, will become one of the most crucial questions of the $21^{\text {st }}$ century. As I see it, willing geographers can either (i) join the large multidisciplinary choir now giving voice to the ailments and demands of our planet or (ii) seek to change its composition and communiques towards more diverse and creative ends. Alas, while the latter is necessary, it is the former that's most likely to eventuate.

I began by recounting recent developments in international geoscience, before turning to the two just identified forms of possible response in Geography. Given the brevity of this essay relative to the size of the topic, I variously gloss, generalise and speculate as I proceed. I also limit my focus to the Anglophone world. Though not forensic, I hope the analysis is nonetheless broadly accurate. At the least, it might stimulate some critical self-reflection among a wide range of geographers interested in society-environment interactions. 


\section{Contemporary geoscience: speaking about, and for, an Earth transformed}

In a germinal 1985 essay, Michael Soulé coined the term 'crisis disciplines' to describe those fields of research and teaching devoted to addressing pressing problems of wide societal relevance. As a scientist, Soulé enjoined his peers to step forward and speak-up for a biophysical world being massively altered by human actions. Thirty years on, it is not just conservation biology - Soulé's own balliwack - that is serving as a crisis discipline. Today, a wide spectrum of geoscientists are reporting alarming changes to all aspects of the 'Earth system'. They study everything from forest ecosystems to hurricanes and use everything from computer models to field experiments in the process. Their research constitutes what is known as global change research (or sometimes global change science).' The solidities of 'global nature' - such as ice-caps and oceanic currents - are, it seems, melting into new biogeochemical fluidities. The knock-on effects for humans and non-humans will be - already are for some - 'game changing' and enduring.

As noted above, teams of researchers have been disseminating a family of plenary concepts in order to register the epic changes afoot. Many also

'Global change research can be traced back to the creation of the four international environmental research programmes created through intergovernmental decision making 25-30 years ago. They were the International Geosphere-Biosphere Program, launched in 1987, which followed the World Climate Research Program, created in 1980. They were followed by the International Human Dimensions Program (1990) and Diversitas (launched in 1991 and focussing on global biodiversity and biogeography). After the Amsterdam Declaration by participating members in 200 I, the programs were connected through a so-called Earth System Science Partnership (which ended in 20I3) and a set of joint projects ensued (see Ignaciuk et al. 20I2). Importantly, global change research has been supported at the national level through various strategies, funding streams and initiatives, such as the multi-sited UK Tyndall Centre for climate change research and policy. Internationally, its institutional face has been the Intergovernmental Panel on Climate Change and the newer Intergovernmental Platform on Biodiversity and Ecosystem Services. The Panel and Platform relate to well-known United Nations efforts to mitigate anthropogenic climate change and protect biodiversity. Under the auspices of the UN Environment Program, UNESCO, the International Council of Science, the International Social Science Council the Belmont Forum and others a new Future Earth initiative will offer strategic direction for global change research in the decade ahead. These formal elements of global change research aside, a much wider 'ecosystem' of inquiry exists to support it grounded in the ordinary activities of researchers in the geosciences in universities. These elements intersect with existing fora for considering globally important environmental issues, such as the periodic World Conservation Congress. In some cases, individuals and collectives have emerged adjacent to the formal elements listed above. Examples are the 'sustainability science' advocated by Robert Kates and others, and the Resilience Alliance emergent from C. S. Holling's (1986) work. More recently, the above mentioned teams promoting the idea of the Anthropocene and planetary boundaries might also be said to contribute to global change research. Overall this research lacks tight coherence, spanning as it does multiple disciplines and involving field-based and computational forms of inquiry. Two useful overviews are provided by Rice (20I5) and Mooney et al. (20I3). 
attended the high-profile 'Planet Under Pressure' science conference in 20I2, purposely organised just prior to the Rio+20 Earth Summit. They continue to publish major works of empirical synthesis in world-leading science journals. Examples are a recent global review of animal biodiversity published in Science (Dirzo et al., 2014) and one about local-scale terrestrial biodiversity across the globe (Newbold et al., 2015). Articles like this tell a story of escalating environmental destruction, notwithstanding the many laws, international agreements, organisations and global fora dedicated to 'protecting the planet'. During the great wave of environmental concern before and immediately after the first Earth Day (in 1970), a few environmental scientists became prominent critics of 'the human impact' (one was Soule's doctoral thesis adviser, the neoMalthusian Paul Ehrlich). Today, by contrast, significant numbers of scientific researchers are speaking-out about the unprecedented effects humans are having on water, land and air. Their collective work informs the recent writings of several environmentalists and journalist-authors who warn us, using nontechnical and often dramatic language, of a less hospitable Earth-to-come (Klein, 20I4; Kolbert, 20I4; Lynas, 20I4; McKibben, 20II; Vince, 20I4). ${ }^{2}$

The reasons that geoscientists are expressing their concern are not hard to seek. On the one hand, more extensive and accurate environmental monitoring systems enable them to detect anthropogenic change with greater precision; better models also allow them to more reliably predict future patterns of biophysical change; finally, interdisciplinary work among geoscientists is now a more established practice than in previous decades, enabling a more woven understanding of anthropogenic forcings and biophysical responses. ${ }^{3}$ One the other hand, however, decision-makers have serially refused to steer contemporary societies in a less environmentally destructive direction - this despite the lead given by the United Nations reaching back nearly 50 years. This refusal is epitomised by the failures of climate change policy since the first Earth Summit in 1992: greenhouse gas emissions into the global atmosphere have not abated and all eyes are now on the late 2015 UN meeting in Paris.

\footnotetext{
${ }^{2}$ At the same time, eminent individual scientists are imploring us to take note and act decisively (e.g. entomologist Edward O. Wilson, author of The Social Conquest of Earth [2012]).

3 One reason for this is the four above-mentioned global environmental change research programmes established 25-30 years ago. The many collaborative projects the programs spawned gave numerous geoscientists (and some social scientists) experience of sustained cross-disciplinary team work.
} 
Given this context, a number of geoscientists have lately enjoined their colleagues to consider making three changes to their professional practices. The first pertains to science communication and arises from two specific concerns. One is that for too long many geoscientists have pulled their punches, hedging their conclusions in terms of 'probability', 'possibility' and 'uncertainty'. As Kevin Anderson and Alice Bows of the UK Tyndall Centre note of climate experts, they "... repeatedly and severely underplay the implications of their analyses" (2012: 640). They then urge their peers to "Liberate the science from economics, finance and astrology and stand by the conclusions, however uncomfortable" (ibid.; see also Sayre et al., 2013). The other concern is that geoscientists have, with some exceptions (like the Intergovernmental Panel on Climate Change working group I), paid insufficient attention to non-academic audiences when presenting their consequential research findings (see Rapley \& De Meyer, 2014). As a result some are now purposefully addressing politicians and others, driven by a sense of professional responsibility. A recent example is the team led by Anthony Barnosky who authored the Scientific consensus on maintaining humanity's life support systems in the $2 I^{\text {st }}$ century: information for policy makers (Barnosky et al., 20I4).

Added to these pleas for more vocal and outward-focussed science communication are calls for geoscientists to focus less on basic research into the changing Earth system. While vital, such research is now seen by many as too divorced from the so-called 'human dimensions' of global environmental change. This implies a need for geoscientists to work together with those researchers who study peoples' values, perceptions, habits, relations, identities and institutions (Reid et al., 20I0; Tavoni \& Levin, 20I4). James Syvitski, chair of the International Geosphere-Biosphere Programme (IGBP), argues for a move "beyond the natural sciences to forge new research interactions with the social sciences, economics, business and law" (20I4: 856). Echoing this, David Victor notes that " $[w]$ hat really matters now are answers to questions about human behaviour ... - the realm of the social sciences and the humanities that ... governments have been most uncomfortable letting into the room" (20I4: 854). For instance, according to this logic research into geoengineering would benefit from close scrutiny of the diverse social barriers to climate change mitigation in different parts of the world. Depending on the (in)tractability of these barriers, certain geotechnical interventions are feasible, others futile in the court of public opinion. So-called 'convergence research' would thereby integrate environmental, technical and social inquiry at the levels of both 
'diagnosis' and 'cure' (see Goldhaber, 20I0; Sharp \& Leshner, 20I4; Weaver et al., 2014). A current example is 'ecosystem services' research which marries biology with economics and ethnobotany. At a more macro-level, late 2015 should see global environmental stewardship enjoy parity of esteem with reformulated human development goals as the UN revisits its 'grand challenges' for the years ahead. ${ }^{4}$ This implies wholesale interdisciplinarity in research, policy and practice.

Finally, some have linked this new emphasis on interdisciplinary inquiry to arguments for more 'decision-relevant' and 'actionable' forms of global change science. For instance, here is Margaret Palmer, director of the National Socio-Environmental Synthesis Center in Maryland. Writing in Bioscience she urges "a new path in which the research process starts with policy needs instead of ending with them ..." (20I2: 6). Relatedly, writing about "practicerelevant adaptation science' in Science R. H. Moss and colleagues state that "Decision-makers are concerned with cost, feasibility, social acceptance, tradition and other factors. To close a 'usability gap', scientific information must fit into existing contexts. Organizational, cognitive, political, ethnographic and decision sciences research is needed [to understand] ... the context in which the information will be applied" (2013: 696). This claim is echoed by Paul Stern et al. (2013) in their argument for 'climate vulnerability science' and by Christa Clapp et al. (2015) who advocate for climate research relevant to green finance. Meanwhile, Wolfram Mauser and colleagues (20l3) advocate for the co-creation of knowledge with a wide array of stakeholders.

\section{Geography and global change research: opportunities born of current contributions}

These calls for change gesture towards something like 'Mode 2' research (Gibbons et al., 1994) which is problem-driven, has applied outcomes and is coproduced with stakeholders. They are occurring at a formative moment in the institutional configuration of global change research (hereafter GCR). The longstanding programmes devoted to interrogating Earth surface transformations (like the IBGP) are today being reformatted and repurposed under a Future Earth umbrella. ${ }^{5}$ Though in its early stages, it's already clear that Future Earth will focus as much on the 'social heart of environmental change' (Hackmann et

\footnotetext{
4l'm referring to the new Sustainable Development Goals, the high-level strategic objectives for UN member states.

${ }^{5}$ Refer back to note I.
} 
al., 2014) as on the biophysical processes and outcomes. It is clear too that the research it facilitates will aim to be 'relevant' to government, communities, businesses and others. A major theme will be 'transformation', of both environments and societies alike (see Future Earth, 2014; Mauser et al., 2013). At the least, this promises to deliver knowledge dedicated to engendering strong reform in the way we collectively live.

All this will seem like manna from heaven to many geographers who examine human-environment interactions. Among the few long-standing disciplines devoted to bridging the 'society-nature divide', Geography is today well placed to contribute to the future of GCR. A great many practitioners are already, and will in years to come be, part of the multidisciplinary networks and debates that constitute this field of fields. This contrasts with 50 years ago when relatively new 'interdisciplines', like environmental science, emerged on the wave of 1960s concern about 'the human impact'. The fields stole a march on Geography at that time, but contemporary Geography is better positioned. What explains the difference?

First, the importance of remote sensing and GIS in Geography from the 1970s onwards - initially supplements to traditional cartography - have given many practitioners considerable expertise in monitoring and measuring Earth surface change. This has been coincident with a growing pace and magnitude of such change due to human influence. Second, Geography's traditions of fieldwork and multi-method analysis have lent themselves to addressing complex processes of human causes and environmental responses at local and regional scales. This is well evidenced in the sort of in-depth research into land cover change conducted by Eric Lambin and Billie Lee Turner II. Third, Geography's tradition of analysing 'natural hazards' has fed into more recent cross-disciplinary research into anthropogenic environmental threats, risks and social responses (be they preventative or reactive). Fourth, after the critique of idiography in the 1950s and 60s, geographers took an increasingly interest in interconnections stretched-out across space and unfolding unevenly through time. By the time 'global warming' became a leading scientific issue, several geographers had the conceptual and technical tool-kits necessary to comprehend 'distantiated' human impacts on nature (see Turner II \& Clark, 1993). Finally, Geography's long-standing topical heterodoxy has allowed a range of expertise to develop into virtually all aspects of the drama of humanenvironment relations. For instance, as far back as the early 1980s research into the ecology of cities was rubbing shoulders with research into rangeland 
management and inquiries into water pollution. Nearly 40 years on and geographers are able, separately and together, to encompass something of the breadth connoted by the so-called 'grand challenges' posed by escalating global environmental change.

Against this background, it is no surprise that numerous geographers have been part of the wider intellectual and institutional fabric of GCR for a number of years. Indeed, Geography's weak connections to the 'environmental agenda' 50 years ago no doubt directly impelled some to avoid repeating the mistake. Aside from Lambin and Turner II, there are important contributors like Diana Liverman, John Barnett, Neil Adger, Katrina Brown, Kirstin Dow, Tim Lenton, William Solecki, Frans Berkhout, Richard Aspinall, Bill Adams, John Dearing, Thomas Downing, Mike Hulme, Robin Leichenko, Karen Seto, Susanne Moser, Martin Parry, Colin Polsky, Mark Pelling, Tom Wilbanks, Mark Rounsevell, Petra Tschakert and Karen O'Brien. Not all of these self-identify as 'geographers', but they are almost all' trained as geographers or else based in academic units where Geography is the main or partial umbrella for research and teaching. Many others like them undertake a similar range of inquiries into how humans alter the Earth and how they might now best respond. ${ }^{7}$

Together, their intellectual and institutional efforts have already made a notable, positive difference to GCR in various of its nodes and networks. For instance, going back some years contributors like Liverman (e.g. 200I) highlighted uneven forms of social vulnerability to environmental change as a key 'human dimension' that policy makers and others need(ed) to take seriously. John Barnett (e.g. 2005), to take another example, was one of those fleshing-out what 'adaptation' means when much of the academic and policy debate was still focussing on the 'mitigation' of global warming. Then, at the

${ }^{6}$ Wilbanks, after many years in Geography, is now positioned elsewhere. This leads me to observe that many other geographers are also contributing to global change science in locations outside Geography. These include geoscience, environmental science, ecology, and environmental management departments or centres. It's also important to note that many physical geographers are contributing directly and indirectly through their research, even if they are not formally part of things like the IPCC or projects linked with the IGBP, Diversitas, the WCRP or the IHDP. Many examples can be found in the field of Quaternary science.

7 In Geography, the precursors to the work of these individuals loomed large in North America where the likes of Gilbert White, Roger Barry, lan Burton, Ken Hewitt, Roger Kasperson, Robert Kates, and Jean Kasperson exerted some influence. Many are still active. Elsewhere, the likes of Piers Blaikie, Harold Brookfield, Tim O'Riordan, Frank Oldfield and Eckart Ehlers eventually had a formative effect on their peers and a younger generation. However, in the 1960s and 1970s these individuals did not typify wider trends in geographical research and teaching. Today, it's worth adding one person to the list of names given in the main text. Martin Rice, in Australia, has many years of experience as a senior administrator in the world of Earth system science. 
level of theory, Leichenko and O'Brien's book Environmental Change and Globalization: Double Exposures (2008) provided a rich conceptual framework to make sense of complex human-environment couplings spatially and temporally. Aside from such intellectual contributions, there has also been high-level involvement with the institutions of GCR at national scales and above (Wilbanks, Adger, and Barnett are all examples). Looking ahead, Liverman, Berkhout and O'Brien have been centrally involved with Future Earth in its formative stages, with more participation to come.

Given this, many geographers can respond with alacrity to the calls for change issuing from global change scientists across the disciplines. In fact, some have lent their voice to these collective declarations. For instance, biogeographer Erle Ellis, along with Lambin, Liverman and Turner II, coauthored a short manifesto calling for a 'new social contract' between global change researchers and the societies they serve (DeFries et al., 2013). ${ }^{8}$ It argues for "solutions-oriented research to provide realistic, context-specific pathways to a sustainable future" (p. 603). This agenda dovetails with what many geographers can offer GCR today. Aspirations to be 'relevant', close attention to geographical particularity and sensitivity to the detail of humanenvironment engagements already characterises much of their research. This is often underpinned by experience of working collaboratively with others, of blending techniques and data, and of responding to 'stakeholder' needs (some of which are overtly political, as with environmental justice and environmental security agendas).

Looking forward, geographers are in many ways well primed to explore the increasingly prominent human aspects of the society-environment nexus in the Anthropocene. Research into adaptation, social resilience, social vulnerability, risk perception, risk assessment, hazard preparedness, resource management, nature conservation and environmental governance has considerable volume and substance in Geography today. Much of it is formally referenced to global environmental change. Unlike some other approaches to people abroad in the wider environmental social sciences, this body of research typically offers a multifaceted and situated sense of 'human dimensions'. Given this, and in light of long-running debates in Geography about 'policy relevance', it is not too hard to see geographers being of value in the new push to make GCR more interdisciplinary and actionable.

8More recently Diana Liverman lent her name to a powerful plea for decision-makers to wake-up to the serious implication of the most recent IPCC assessment report (Rockström et al., 20I4). 


\section{A different future for Geography and global change research?}

The above sketch suggests that many geographers, and therefore perhaps Geography as a subject, now stand/s to enhance their/its contributions and reputation/s in the wider domain of GCR. With eyes on the future, this is all to the good. However, a few leading geographers who work in this area have raised some important concerns. Especially noteworthy are recent contributions by Karen O'Brien and Mike Hulme (a geographer-turned-climate scientist-(re)turned geographer). In different ways, both detect a problematic conservatism abroad in GCR, despite its expressed aim to respond urgently to a worldwide 'environmental crisis'. In different ways they see the need and potential for geographers to influence GCR in novel ways. As I see it, such influence will be crucially tied to the numbers (and thus visibility) of the geographers involved. Let me explain.

The recent high-level World Social Science Report (sub-titled Changing Global Environments) attempts to push the envelope in terms of how 'human dimensions' are conceived and to what ends they might in future be steered by decision-makers (ISSC, 20I3). While economics, business studies, behavioural psychology and the study of political institutions have loomed large in recent debates about reducing the human impact on Earth, the Report ranges further afield. In her contribution to this agenda-setting volume, O'Brien (20I3a: 74) calls for a "deeper approach". She notes the "potential and capacity of humans to recognise, understand and respond to environmental change by addressing the social structures that promote and perpetuate these changes" (ibid.). She goes on to highlight the preoccupations of critical social science and the need for knowledge that can help "transform ... the systems ... that favour some interests over others ... and develop new types of power and leadership for change" (p. 77). ${ }^{9}$

Coincident with this intervention, O'Brien has reflected on Geography's role on GCR at length in the pages of Progress in Human Geography (O'Brien, $2010,2012,2013 b$ ). Because of the discipline's rich traditions of critical scholarship and human-environment inquiry (encapsulated, notably, in political ecology), she sees high potential for many geographers to deliver the deeper

'O'Brien's vision for environmental social science in the CGR context differs from the rather scientific-analytical representation offered by Emilio Moran in his plenary account Environmental social science (20I0). It is more in keeping with Vaccaro et al.'s (2010) pleasingly ecumenical vision. 
approach she commends. "The door is now open for social scientists to shape a new science for global change", she notes, "[but] it is up to ... geographers to go through that door - otherwise it is unlikely that critical or reflexive social science will be pulled in ..." (2010:547). ${ }^{10}$ A recent example of where such interventions would be useful appeared in the pages of Science. There Karen Seto and others make the case for more sophisticated 'systems integration' so as to better understand coupled environmental and societal changes (Liu et al., 20I5). While a sound argument within its own terms of reference, it risks ontological monism: that is, perpetuating the questionable presumption there is only one world amenable (at least causally) to understanding through a single epistemological template. More broadly, the strategic vision for Geography presented in a notable National Research Council report (Murphy et al. 2010) tends likewise to offer a rather narrow sense of how to articulate with GCR.

Like O'Brien, Mike Hulme similarly worries that the mix of knowledge contributing to a new phase of 'coupled' GCR may be insufficiently broad without some strategic intervention. However, he more strongly emphasises the contributions of the humanities than does O'Brien. For instance, in a recent essay Hulme (20l4a) notes the absence of any meaningful discussion of 'virtue' in either geoscience debates about the future of Earth or public debates about the same. This is well evidenced in recent discussions of geoengineering in the journals Nature and Nature Climate Change (Barrett et al., 20I4; Keith \& MacMartin, 20I5; Long et al., 2015). For him the problem is selfreinforcing because the visibility of geoscience in the 'human impact' debate fosters a narrow framing of the issues in the wider society (which then legitimates geoscience's approach). A much broader framing is called for in his view that explores how 'problems' of, and 'solutions' to, global environmental change look when we explore them through complex virtues like wisdom, humility, integrity, faith, hope and love. In this light, he regards high-risk geoengineering proposals as dangerous (intellectually as much as practically) because conceived absent any substantive sense of virtue (Hulme, 20I4b).

Hulme's arguments give a clear sense of why he returned to Geography after 25 years in an environmental science school at the University of East Anglia." The discipline has high 'band width' and is unusually heterodox. As he

\footnotetext{
10Interestingly the American Anthropological Association has recently pondered anthropology's recent and future role in shaping understandings of climate change (see Fiske et al., 20I4).

"Hulme is now in Geography at King's College, London.
} 
stated in a 2008 article on Geography and climate change, potentially the subject is able to hold scientific and cultural understandings of nature in productive tension, acknowledging the equal validity of 'objective' and 'subjective' forms of knowledge (Hulme, 2008). This differentiates it from most other subjects contributing to GCR today, and it creates opportunities for wide and deep connections between varied kinds of knowledge about the material and semiotic worlds that humans inhabit.

Together, O'Brien and Hulme argue that geographers can help change, rather than conform to, dominant currents of inquiry in the world of GCR. Their arguments point to currently unrealised potential to constructively challenge the social interests that GCR, as currently constituted, dovetails with. For instance, there is a sophisticated body of writing in human geography on 'post-politics', led by Erik Swyngedouw. He (e.g. 20l0) argues that, far from challenging the present social order, climate science contributes to a situation where things like carbon trading are touted as the best way to address what is, fundamentally, a problem of capitalist political economy not mere 'negative externalities'. At the same time, a number of geographers inspired by Michel Foucault's influential writings have shown how various geoscience fields are 'biopolitical' - that is, they internalise 'rationalities of rule' specific to early $21^{\text {st }}$ century Western neoliberal societies (see, for instance, Biermann \& Mansfield, 2014). In more policy relevant vein, others have shown that certain styles of environmental social science get locked-in to status quo approaches to managing natural resources and human behaviour alike (e.g. Pearce et al., 2013). Here productive interference between different forms of geographical knowledge can pay dividends, as Darla Munroe and co-authors (2014) show in the case of land change science and post-positivist economic geography.

Critique aside, other geographers have been inspired by geoscience to think deeply about foundational categories of analysis and normative reasoning. For instance, Kathryn Yusoff (2013) takes the announcement of the Anthropocene as an occasion to rethink the 'anthropos': for her, the human as a causal actor and bearer/recipient of moral obligations threatens to dissolve in our world of epic entanglements among forces, processes and entities. She regards this as positive rather than merely destabilising. Her arguments thereby implicitly challenge the calls for 'stewardship' and 'planetary management' found in the writings of geoscientists like Paul Crutzen and Will Steffen (e.g. Steffen et al., 20l I). This is because these calls rest on an unproblematised notion of 'the human' as a species now (supposedly) obliged to take 
responsibility - as master and caretaker - for an Earth it has been too careless with.

Currently, for all their interest, interventions like these are typically directed at like-minded geographers rather than at global change researchers within and without the discipline. They exemplify the insularity of the wider social sciences and humanities identified in a recent citation analysis of the 'three cultures' divide in academia (Tavoni \& Levin, 20 I4: 1058). I say this as someone whose career as a geographer has been indebted to the critical and interpretive traditions so richly developed since the early 1970s. 'People like us' are, like many people, most comfortable when speaking to those we know, in journals, workshops and conference sessions that attract fellow-travellers. If writings by the likes of Erik Swyngedouw and Kathryn Yusoff are anything to go by (indeed my own writings), the potential O'Brien and Hulme identify is not (yet) being realised. We need to begin a process of more fulsome engagement with the wider world of GCR, alien though it will be to very many of us.

To some extent this has already occurred in conservation biology since Michael Soulé proclaimed its crisis-avoidance mission. For instance, geographer Bill Adams has been a long term bridge-builder between the biological sciences and critical social science thinking about the means and ends of conservation (see, most recently, Adams, 20I4). In recent times, a body of 'critical conservation research' has begun to enjoy some visibility in relevant academic and policy arenas (think of work by Dan Brockington [2012], among others). Work like this might inspire others in geography to believe that their research into human-environment relations might, with effort, speak to a broader GCR constituency. As noted earlier, the onset of the Future Earth initiative makes this an important time to frame analytical and normative agendas in GCR. The battle of ideas is harder, but all the more important, once one begins to engage beyond the usual written and face-to-face fora in academic Geography.

Let me note that none of this implies that those individuals I mentioned earlier - like Diana Liverman, Jon Barnett and Katrina Brown - are somehow unaffected by Geography's critical and interpretative toolkits. Quite the opposite. O'Brien is a case in point, so too Hulme. My point is simply that there's a weight of thinking, talent and energy that could be productively channelled into the networks and institutions of GCR. So far, relatively small number of practitioners have had to do the hard, unglamorous work of changing GCR agendas usually dominated by a scientific worldview (in its 
various forms of instantiation). At a formative moment in the life of GCR, a larger involvement by geographers might give other global change researchers pause for thought about what interdisciplinary, actionable research could (and should) look like. ${ }^{2}$

To my mind, in its next phase GCR should serve to pluralise our collective sense of what sort of 'problem' the Holocene's end represents, and what sort of responses are 'appropriate' at different scales (cf. Stirling [20I2] writing in Bioscience). It might explore different 'values-means-ends packages' (VMEPs), where the evidence base and any proposed interventions are made relative to specific moral, spiritual and aesthetic frames (see Castree et al., 2014). These frames would reflect the diversity of human traditions and aspirations, be they majoritarian or marginal. They would highlight the variety of ways that the scientific 'facts' about global environmental change can come to matter, especially when so many 'human dimensions' involve disagreements and conflicts over the kind of life that's worth living. This would necessarily politicise geoscience overtly. Then again, how can one have 'interdisciplinary', 'relevant' GCR without bringing politics into the very heart of the endeavour? This is something that Tim O'Riordan (2004) asked a decade ago, and the question remains deeply germane.

There are recent hints in Geography that some are collaborating in ways that articulate social questions of values, means and ends with scientific questions about biophysical processes and events. These collaborations include those by Sarah Whatmore, Stuart Lane and others (examining flood management - e.g. Lane et al., 20I I) and by Gary Brierley, Richie Howitt and Deidre Wilcock (exploring geomorphology in the context of indigenous cosmologies in Australia and elsewhere - see Wilcock et al., 20I3). Like any collaborative endeavour across the so-called 'human-physical divide' in Geography these are not easy to undertake. Decades of disciplinary debate about the causes of this divide and how to close it attest to this. However, it seems to me that far more physical and environmentally-minded human geographers today have experience of team working where ontological, epistemological and methodological differences need to be negotiated. That

\footnotetext{
12The good news here is that some of the current players have supervised some intellectually interesting graduate students who are now early-to-mid career professionals in Geography and affiliated fields. These former students stand to make a difference within GCR.
} 
offers some hope that more practitioners might make a difference to the future course of GCR if minded to engage this field of fields. ${ }^{13}$

\section{Conclusions}

There are times when the intellectual climate needs to be changed before knowledge and events run a terrible course. The role that the economics profession played in precipitating the global financial crisis is a stark reminder of this truism, even as some now think economists can belatedly stave-off a global environmental crisis (see Helm, 20I5; Stern, 20I5). GCR may, in new forms, come to the fore in the decades ahead. Geography will be part of that process, one way or the other. The question is: will practitioners be weathermakers or climate-changers? The latter is the harder task by far. It requires confidence and fortitude among leading researchers and a sufficient volume of like-minded practitioners to make a difference. But as one ponders the move towards a greater focus on the 'human' in GCR and on practice-relevant research, there are currently few other disciplines that can drive more than one wedge into the enduring conservatism that O'Brien and Hulme detect.

Fields like environmental economics, behavioural psychology and political science typically screen-out the radical and interpretive approaches to societyenvironment relations one finds in contemporary human geography. Yet these fields are typically those that geoscientists think of when they talk about 'human dimensions' and the need to be more interdisciplinary. One of the few exceptions to this is ecological economics, which has enjoyed growing prominence in DIVERSITAS, the IPBES and international ecosystem services scholarship and policy. As O'Brien argues, to change this some of us in Geography will need to change ourselves. We will need to make new friends, write for new audiences, attend new conferences, get ourselves on different sorts of committees and panels. Despite the much derided corporatisation of Western universities, we should not pretend we lack the agency to alter the things we do as researchers and educators. If we do, we simply let an overblown narrative about real, but far from all-encompassing, processes of change in higher education dissuade us from altering our modus operandi. Midand late-career geographers with secure positions are particularly well placed

\footnotetext{
13In effect, I'm taking David Demeritt's (2009) argument for plurality as the preferred mode for human-physical collaborations (as opposed to a singular unity) and applying it to geographers' potential engagements with GCR, engagements that are about 'interference' in Demeritt's terms.
} 
to try new things in those arenas where Geography has something useful to say to global change researchers. ${ }^{14}$

Acknowledgements Many thanks to three anonymous reviewers whose suggestions were most helpful. I am also grateful to David Demeritt and Diana Liverman for setting me straight on some key issues. Any errors of fact or oddities of interpretation are entirely my own.

\section{References}

Adams, W. M. (2014) 'Valuing the value of nature', Science 346, 6209: 349-5I. Anderson, K. \& Bows, A. (2012) 'A new paradigm for climate change', Nature Climate Change 2, September: 639-40.

Barnett, J. (2005) 'Assessing and enhancing adaptive capacity', in I. Burton et al. (eds) Adaptation Policy Frameworks for Climate Change (Cambridge: Cambridge University Press) Pp. I- 17.

Barnosky, A. et al. (20I2) 'Approaching a state shift in Earth's biosphere', Nature 486: 52-8.

Barnosky, A. et al., (20l4) 'Introducing the Scientific consensus on maintaining humanity's life support systems in the $21^{\text {st }}$ century: information for policy makers', The Anthropocene Review I, I: 78-109.

Barrett, S. et al., (20I4) 'Climate engineering reconsidered', Nature Climate Change 4, July: 527-9.

Biermann, C. \& Mansfield, B. (2014) 'Biodiversity, purity and death', Society and Space 32, 2: 257-73.

Brockington, D. (20I2) 'A radically conservative vision? The challenge of

UNEP's Towards a Green Economy', Development and Change 43, I: 409-422.

Clapp, C. et al. (2015) 'Influence of climate science on financial decisions', Nature Climate Change 5, February: 84-5.

Crutzen, P. J. \& Stoermer, E. F. (2000) 'The Anthropocene', Global Change Newsletter 4I: 17-18.

DeFries, Ruth et al. (2013) 'Planetary opportunities', BioScience 62, 6: 603-606.

Demeritt, D. (200) 'Geography and the promise of integrative research', Geoforum

Dirzo, R. et al. (20I4) 'Defaunation in the Anthropocene', Science 345, 6195:

\footnotetext{
${ }^{14}$ In my own case, I have been pleasantly surprised how easy it has been to engage people across the social sciences who are part of the wider GCR world as occasional or more permanent contributors. After co-authoring a commentary in Nature Climate Change in 2014, a number of invitations came my way along with new interlocutors (by email, mostly). Though it's unclear what opportunities await, I feel there's an open door waiting to be pushed. This said, I have as yet had little interaction with geoscientists who measure, model and/or predict the human impact on Earth. The positive difference for environmental social scientists, compared to 20 years ago, is that more geoscientists now recognise that 'human dimensions' are key to their own endeavours. This surely provides an opening for mutually enriching dialogue and action.
} 
$40 \mathrm{I}-6$.

Fiske, S. et al. (20I4) Changing the Atmosphere (Arlington, VA: American Anthropological Association).

Future Earth (2014) Future Earth 2025 Vision (International Council for Science: Paris).

Gibbons, M. et al. (1994) The New Production of Knowledge (London: Sage).

Goldhaber, M. (2010) 'Fostering integrated science', Elements, April: 69.

Hackmann, H. et al. (20l4) 'The social heart of global environmental change', Nature Climate Change 4, August: 653-55.

Helm, D. (20I5) Natural Capital: Valuing the Planet (New Haven: Yale University Press).

Holling, C. S. (1986) 'The resilience of terrestrial ecosystems', in W. C. Clark

\& R. Munn (eds) Sustainable Development of the Biosphere (Cambridge:

Cambridge University Press) pp. 292-317.

Hulme, M. (2008) 'Geographical work at the boundaries of climate change',

Transactions of the Institute of British Geographers 33, I: 5-II.

Hulme, M. (20I4a) 'Climate change and virtue: an apologia', Humanities 3: 299 -

$3 \mid 2$.

Hulme, M. (20I4b) Can Science Fix the Climate? (Cambridge: Polity).

Ignaciuk, A. et al. (20I2) 'Responding to complex societal challenges: a decade of ESSP interdisciplinary research', Current Opinion in Environmental Sustainability 4, 2: 147-58.

International Social Science Council (2013) World Social Science Report (UNESCO \& OECD: Paris).

Keith, D. \& MacMartin, D. (20I5) 'A temporary, moderate and responsive scenario for solar engineering', Nature Climate Change 5, March: 20I-6.

Klein, N. (2014) This Changes Everything (New York: Simon \& Schuster).

Kolbert, E. (20I4) The Sixth Extinction (London \& New York: Bloombury).

Lane, S. et al., (20II) 'Doing flood risk science differently', Transactions of the Institute of British Geographers 36, I: I5-36.

Leichenko, R. \& O’Brien, K. (2008) Environmental Change and Globalization:

Double Exposures (Oxford: Oxford University Press).

Liverman, D. (200I) 'Vulnerability to drought and climate change in Mexico', in

Kasperson, J.X. \& Kasperson, R. (eds) Global Environmental Risk (New

York: Earthscan) Pp. 20I-I6.

Liu, J. et al., (2015) 'Systems integration for global sustainability', Science 347, 6225: 963-72.

Long, J. et al. (2015) 'Start research on climate engineering', Nature 5I8, 
February $5^{\text {th }}: 29-31$.

Lynas, M (20II) The God Species (National Geographic Society: Washington). Mauser, W. et al. (20/3) 'Transdisciplinary global change research', Current Opinion in Environmental Sustainability 5: 420-3I.

McKibben, B. (20II) Eaarth (Henry Holt: New York).

Mooney, H. et al. (20I3) 'Evolution of natural and social science interactions in global change research programs', PNAS I I0, supplement I: 3665-72.

Moran, E. (2010) Environmental Social Science (Oxford: Wiley-Blackwell).

Moss, R. H. et al. (20I3) 'Hell and high water: practice-relevant adaptation science', Science 342, $8^{\text {th }}$ November: 696-7.

Munroe, D. et al. (20l4) 'Using economic geography to reinvigorate landchange science', Geoforum 52, 2: I2-2I.

Murphy, A. et al. (20I0) Understanding the changing planet (Washington: National Academies Press).

Newbold, T. et al. (2015) 'Global effects of land use on local terrestrial biodiversity', Nature 520: 45-50.

O'Brien, K. (2010) 'Responding to environmental change: A new age for human geography?', Progress in Human Geography 35, 4: 542-9.

O'Brien, K. (20I2) 'Global environmental change II: From adaptation to deliberate transformation', Progress in Human Geography 36, 5: 667-76.

O'Brien, K. (20/3) 'What's the problem?', in International Social Science Council (ed.) World Social Science Report 2013 (UNESCO \& OECD: Paris) pp. 7I-8.

O'Brien, K. (20/3b) 'Global environmental change III: closing the gap between knowledge and action', Progress in Human Geography 37, 4: 587-96.

O’Riordan, T. (2004) 'Environmental science, sustainability and politics', Transactions of the Institute of British Geographers 29, 2: 234-47.

Palmer, M. (20I2) 'Socioenvironmental sustainability and actionable science'. BioScience 62, I: 5-6.

Pearce, R. et al. (20I3) 'Re-framing environmental social science research',

Water Resources Management 27, 7: 959-79.

Rapley, C. \& De Meyer, K. (2014) 'Climate science reconsidered', Nature Climate Change 4, September 745-6.

Reid, W. et al. (2010) 'Earth System Science for global sustainability', Science 330, $12^{\text {th }}$ November: $916-7$.

Rice, M. (2015) 'Spanning disciplinary, sectoral and international boundaries: a sea-change towards transdisciplinary global change research?', Current Opinion in Environmental Sustainability 5, 3: 409-19.

Rockström, J. et al. (2009) 'A safe operating space for humanity', Nature 46I, $24^{\text {th }}$ September: $472-5$.

Rockström, J. et al. (2014) 'Climate change: the necessary, the possible and the desirable ...', Earth's Future DOI: I0.1002/2014EF000280 
Sayre, N. et al. (2013) 'Invitation to Earth Stewardship', Frontiers in Ecology and the Environment II, 3: 339-339.

Sharp, P. \& Leshner, A. (2014) 'Meeting global challenges', Science 343, $7^{\text {th }}$ February: 579.

Sorlin, S. (20I3) 'Reconfiguring environmental expertise', Environmental Science and Policy 28, I: I4-24.

Soulé, M. (2005) 'What is conservation biology?', BioScience 35, 8: 727-34.

Steffen, W. et al. (2004) Global Change and the Earth System (Berlin: Springer).

Steffen, W. et al. (20II) 'The Anthropocene: from global change to planetary stewardship', Ambio 49, 5: 739-761.

Steffen, W. et al. (2015) 'Planetary boundaries: guiding human development on a changing planet', Science 347, 6223: 736-46.

Stern, N. (2015) Why Are We Waiting? (Cambridge, Mass: MIT Press).

Stern, P. C. et al. (20I3) 'Managing risk with climate vulnerability science', Nature Climate Change 3, July: 607-9.

Stirling, A. (2012) 'Opening-up the politics of knowledge and power in bioscience', PLOS Biology 10, I: I-5.

Swyngedouw, E. (2010) 'Apocalypse forever?', Theory, Culture \& Society 27, 2-3: 213-32.

Syvitski, J. (20I4) 'Looking forward', Nature Climate Change 4, October: 856-7. Tavoni, A. \& Levin, S. (2014) 'Managing the climate commons at the nexus of ecology, behaviour and economics', Nature Climate Change 4, December: 1057-63.

Turner II, B. L. \& Clark, W. (eds) (1993) The Earth as Transformed by Human Action (Cambridge: Cambridge University Press).

Victor, D. (2014) 'Copenhagen II or something new?', Nature Climate Change 4, October: 853-5.

Vaccaro, I. et al. (eds) (2010) Environmental social science (Cambridge: Cambridge University Press).

Vince, G. (2014) Adventures in the Anthropocene (London: Chatto \& Windus)

Weaver, C. P. et al. (2014) 'From global change science to action with social sciences', Nature Climate Change 4, August: 656-9.

Wilcock, D., Brierley, G. \& Howitt, R. (2013) 'Ethnogeomorphology', Progress in Physical Geography 37, 5: 573-600.

Wilson, E. O. (20I2) The Social Conquest of Earth (W. W. Norton: New York).

Yusoff, K. (2013) 'Geologic life: prehistory, climate, and futures in the 
Anthropocene', Society \& Space 3I, 5: 779-95. 